\title{
EL «CHINO" Y EL «INDIO»: PEDRO S. ZULEN Y JULIO C. TELLO, UNA AMISTAD DEL NOVECIENTOS A TRAYÉS DE SU CORRESPONDENCIA, 1914 - 1922
}

Miguel Ángel del Castillo Morán

María Moscoso Carbajal

\section{RESUMEN}

El presente artículo trata sobre la relación entre dos importantes intelectuales e indigenistas limeños de la generación del «novecientos». Los autores adjuntan, a manera de apéndice, la correspondencia intercambiada por ambos en un lapso de ocho años.

\section{ABSTRACT}

The present article is about the relationship between the two important intellectual and indigenistas limeños of the "nineteenth century» generation. The authors joins, as an appendix, the correspondence exchanged by each other in the lapse of eight years.

Arqueología y Sociedad No 14, 2002: 165-188

Museo de Arqueología y Antropología

Universidad Nacional Mayor de San Marcos 
E proceso de recuperación y rescate de los intelectuales de la denominada «generación del $900 »$, es decir, de aquellos nacidos entre los años de 1877 y $1891^{1}$, se inició a partir del centenario del nacimiento de Víctor Andrés Belaunde (Planas 1994: 7). Resultado de este fenómeno fue la aparición de las primeras obras publicadas sobre el tema, por autores como Luis Loayza (1990), Pedro Planas y Osmar Gonzales (1996), que han venido a modificar sustancialmente el panorama que sobre los movimientos intelectuales de las primeras décadas del siglo $\mathrm{XX}$ tenemos en la actualidad.

Este renovado interés por el $900 \mathrm{y}$ sus intelectuales, que concentran hoy la atención prestada con anterioridad a los miembros de la «generación del Centenario», que tuvo como máximos exponentes a Haya de la Torre y Mariátegui, se ha visto limitado, sin embargo, por el deslumbramiento producido por pensadores de la talla de Francisco García-Calderón, José de la Riva-Agüero y Víctor Andrés Belaunde, que han acaparado prácticamente el interés de los investigadores y estudiosos del pensamiento político peruano. Estas grandes figuras, aunque influyentes, son finalmente individualidades al interior de un movimiento generacional universitario mucho más vasto -política, social y culturalmente-en San Marcos, pero también en las denominadas universidades menores del Cuzco, Arequipa y Trujillo. El 900, desde esta perspectiva, se nos revela, aún, como casi desconocido e inexplorado. ${ }^{2}$

Asimismo, existen intelectuales novecentistas a los que podríamos calificar de «atípicos», como Julio C. Tello (1880-1947) y Luis E. Valcárcel (1891-1987), los más destacados y conocidos exponentes del indigenismo peruano desde el campo de las cien- cias sociales y que no necesitan de mayor presentación, pero a quienes cuesta todavía identificar o percibir como a miembros de su generación ${ }^{3}$. Algo similar ocurre con Pedro S. Zulen (1889-1925) y Francisco Chukiwanka Ayulo (1877-1957), verdaderos gigantes del indigenismo novecentista que, sin embargo, apenas hoy comenzamos a descubrir.

La publicación de la, hasta ahora inédita, correspondencia intercambiada por Pedro $S$. Zulen y Julio C. Tello durante la segunda y tercera décadas del siglo pasado, obliga a hacer un paralelo entre ambas biografías y a descubrir en ellas una serie de rasgos comunes. Entre ellos cabe mencionar: los problemas ocasionados por sus orígenes «raciales" y socioeconómicos; el ingreso a la misma sección y facultad en la Universidad de San Marcos; el temprano interés por los temas de investigación antropológica y la defensa de los derechos del indio, aunado a su condición de miembros de la Asociación Pro Indígena; sus estudios en la Universidad de Harvard y su gran admiración por la cultura estadounidense; su interés por la política, expresado en sendas candidaturas al Congreso de la República, por provincias colindantes; y sus ideas de reforma de la Universidad, anteriores a 1919.

\section{UNA AMISTAD DEL NOVECIENTOS}

Tello, nacido en las alturas de la provincia limeña de Huarochirí, de madre indígena y padre mestizo, llegó a Lima en marzo de 1893 para terminar su instrucción primaria e iniciar la secundaria, viéndose obligado a trabajar para subsistir luego de la muerte de su padre, en 1895 (Mejía Xesspe 1964: 54, 66-68). Es en estas circunstancias que debió sufrir, seguramente, el doble estigma de ser señalado como «indio» y «serrano ${ }^{4}$. 
Curiosamente, es alojado en una modesta pensión del jirón Ilave, muy cerca de la plaza del Cercado en los Barrios Altos, es decir, la misma calle adonde se mudarían los Zulen años después 5 . En 1900, Tello ingresa a la Facultad de Ciencias de la Universidad de San Marcos, como paso previo a sus estudios de medicina en San Fernando (Mejía Xesspe 1948: 8-10; 1964: 69-77)6.

Zulen, de madre mestiza y padre chino, aunque limeño de nacimiento, debió sufrir desde pequeño el menosprecio de una sociedad que veía la inmigración oriental como una amenaza, y calificaba de «injertos» al resultado del cruzamiento entre chinos y peruanas $^{7}$. En 1906 ingresa a la Facultad de Ciencias, y solicita una exoneración del pago de derechos de matrícula, alegando «escasez de recursos».

Mientras Tello parece definir tempranamente, entre 1899 y 1903 , su vocación e interés por la antropología y arqueología andinas, Zulen manifiesta, en 1909, un fuerte interés por la defensa de los derechos indígenas, influido seguramente por la prédica de Santiago Giraldo, Joaquín Capelo y Dora Mayer. Ese mismo año es nombrado secretario general de la Asociación Pro Indígena, institución gestada en sus orígenes al interior del Centro Universitario de Lima, primer gremio estudiantil peruano, fundado en $1908^{8}$. Tello sería incorporado más tarde como miembro de la Asociación, decisión que poco tiempo después le permitió obtener un importante respaldo durante su excursión arqueológica de 1915, para ser recibido y apoyado en sus investigaciones por los «delegados» que la Pro Indígena tenía en todo el sur del país (documento $\left.\mathrm{N}^{\circ} 2\right)^{9}$.

Mientras Zulen abandona pronto sus estudios para dedicarse íntegramente a la labor indigenista, Tello viaja becado por el gobierno a los Estados Unidos y realiza sus estudios de postgrado en la Universidad de
Harvard (1909-11) y luego se traslada a Inglaterra, Alemania y Francia, de donde retornará al Perú en enero de 1913 (Mejía Xesspe 1964: 80-83). Becado igualmente por el gobierno, Zulen viajaría a Norteamérica hasta en dos oportunidades: la primera de ellas en 1916, permaneciendo en Harvard pocos meses, y la segunda entre 1920 y 1922, realizando estudios de filosofía, psicología y lo que hoy conocemos como bibliotecología. Esta última especialización permitió al rector Manuel Vicente Villarán nombrarlo, en 1923, director de la Biblioteca de San Marcos, en la que Zulen inicia un vasto proceso de modernización ${ }^{10}$. Los estudios en la Universidad de Harvard comprueban la gran devoción que ambos personajes sentían por los Estados Unidos y su cultura. Tello incluso llegó a pensar en radicar definitivamente en Norteamérica (documento $\mathrm{N}^{\circ} 6$ ). Una amistad en común escribiría:

“Es posible que Tello no me hablara nunca de París? ¿Es comprensible que a un hombre de tanto talento no le haya impresionado este maravilloso receptáculo de la cultura greco-latina? ¿Es posible que el culto anglo-americanista sea tan absorbente que unilateralice la mentalidad de personas como Tello y Zulen, haciéndoles considerar de poca importancia lo que no es genuino de Estados Unidos, en lo que se muestran más papistas que el Papa, pues los yankees gustan de beber en todas las fuentes.... aunque a veces se atraganten?"."

El origen de la relación entre Pedro S. Zulen y Julio C. Tello es algo incierto ${ }^{12}$. Con toda seguridad, no se conocieron sino hasta el retorno de Tello al Perú, en 1913. Recuérdese que hacia 1909 ambos estudiaban en locales distintos, el primero lo hacía en San Carlos y el segundo en San Fernando; que mientras uno cursaba el primer año de Letras, el otro se doctoraba en Medicina con honores; que durante las «Conversaciones 
Universitarias», al abordarse el tema del problema de la educación indígena, Tello no figura como uno de los muchos comentaristas espontáneos a pesar de ser ya un egresado sobresaliente; y que mientras Tello arribó a la ciudad de Nueva York en el mes de setiembre, la Asociación Pro Indígena se fundó, a instancias de Zulen; recién hacia fines de noviembre.

Al parecer, Zulen gestionó en 1913 su nombramiento como funcionario en el Museo de Historia Nacional, sin ningún éxito. Por entonces Tello, jefe de la sección arqueológica de esta institución, iniciaba una sonada polémica con su director, Emilio Gutiérrez de Quintanilla, destacado intelectual y miembro de la Asociación Pro Indígena ${ }^{13}$. Las relaciones con este último, sin embargo, no deben haber sido muy buenas pues, como revela una primera comunicación del 27 de enero de 1914, Zulen se dedicó a cultivar su amistad con Tello (documento $\mathrm{N}^{\circ} 1$ ).

Producido el golpe de estado contra el régimen de Billinghurst, se constituye por disposición del Congreso una junta de gobierno con participación de todas las fuerzas políticas, que incluía, como ministro de Gobierno, a un miembro del Partido Constitucional y amigo de Zulen: don Arturo Osores. Quedaba abierta, de este modo, la posibilidad de lograr por fin la ansiada colocación y aliviar su dramática situación económica. Una serie de cartas suscritas por Joaquín Capelo, congresista del Partido Demócrata y presidente de la Asociación Pro Indígena, lo confirman ${ }^{14}$. Por razones que desconocemos, el nombramiento de Zulen en el Museo no prosperó, aunque es muy probable que se debiera a la enemistad entre Gutiérrez de Quintanilla y Tello, así como al escaso interés del gobierno por el recién creado museo arqueológico, que impidió realizar las modificaciones propuestas por Tello y obtener un mayor presupuesto que incluyera nuevos nombramientos (Tello y Mejía 1967: 98). ${ }^{15}$

El porqué del interés de Zulen en el Museo de Historia Nacional puede deducirse, tal vez, por el contenido de su archivo de recortes periodísticos, en donde destacan algunos de los artículos que el ilustre historiador Manuel González de la Rosa (18411912) publicara èn la prensa de la época. A su preocupación por el indio como principal integrante de la problemática social del Perú contemporáneo, agregaba el joven Zulen un interés por su historia desde tiempos prehispánicos, como demuestra en un artículo sobre el problema de la educación nacional (Zulen 1909), donde aborda tempranamente el tema de la educación incaica.

Ambos personajes compartieron también el interés por la política. Tello, postulado inicialmente por el PND de Riva-Agüero, fue electo diputado por su provincia natal en períodos consecutivos desde 1917 hasta 1929. Con el inicio del llamado «oncenio» del presidente Augusto B. Leguía (1919-30), se convirtió en uno de sus más destacados colaboradores, adhesión que provocó su detención tras la caída del régimen, acusado de diversos delitos de corrupción que no pudieron probarse, por lo cual fue libera$\mathrm{do}^{16}$. Zulen, en cambio, lanzó su candidatura en 1919 para una diputación suplente por la provincia de Jauja, y fue abruptamente detenido por orden del subprefecto tras un radical discurso a los indígenas del pueblo de Marco. Rápidamente, sus amigos parlamentarios, Tello y Capelo, iniciaron una campaña a favor de su libertad y la obtuvieron con apoyo del propio presidente de la República, el civilista José Pardo:

“[...] en seguida hizo telegrama preguntando al subprefecto la causa de su prisión; a los dos días y después de reiterar la pregunta vino como respuesta que usted era un gran civilista, y como si ello fuese un deli- 
to, en eso se radicaba su prisión. Llevado el telegrama al presidente y con el apoyo del director [de Gobierno] se dio la orden de libertad [...]. Mucho ha facilitado el resultado obtenido los artículos a favor de usted que publicaron La Crónica $y$ La Razón en sección oficial y el concepto que en esos periódicos se hizo de su persona. En el de La Crónica tuvo parte principal su amigo el diputado Tello". ${ }^{17}$

El hecho determinó, sin embargo, el final de la corta carrera política de Zulen. Años atrás, nuestros personajes compartieron una inquietud común con relación al papel jugado por la Universidad en el proceso de la educación nacional, interés que los llevó a publicar algunos artículos sobre el tema. En 1913, la revista de los estudiantes publicó un artículo de Tello en donde éste realiza un paralelo entre las universidades de Harvard y San Marcos, partiendo de su propia experiencia en los Estados Unidos (Tello 1913). $\mathrm{Al}$ año siguiente, Zulen hizo lo propio en un polémico artículo en donde planteó una especie de diagnóstico acerca del estado en que se hallaba el alumnado y su escasa disposición para el estudio y la investigación, condenando al mismo tiempo a encumbrados miembros de su propia generación, ya convertidos en catedráticos (Zulen 1914b). Zulen fundó por ello la Sociedad «Ethos» buscando "producir una reacción contra esos hábitos poco edificantes, que introducen una anarquía deplorable en la vida universitaria y que alejan a la juventud de su verdadero papel" (Zulen 1914a) ${ }^{18}$, y publicó cinco años después dos artículos refiriéndose al mismo tema abordado por Tello en 1913: las diferencias entre San Marcos y Harvard (Zulen 1919, 1919-20) ${ }^{19}$. En su correspondencia epistolar, ambos intelectuales intercambiaron opiniones críticas sobre la problemática universitaria de su tiempo, exponiendo la necesidad de reformar y moralizar radicalmente la institución (documento $\mathrm{N}^{\circ} 14$ ), la ineficacia de las misiones norteamericanas promovidas desde el gobierno (documento $\mathrm{N}^{\circ} 12$ ), el receso de 1921 y su mutua enemistad con Víctor Andrés Belaunde (documentos $\mathrm{N}^{\circ} 5,8$ y 9 ), la reorganización de la Biblioteca (documento $\mathrm{N}^{\circ}$ $15)$, entre otros. Tello terminaría confesando a su amigo:

"Una vez yo mismo censuré la forma acalorada de algunos de sus artículos referentes a la mala organización de la universidad; creíque no era tanto ignorancia de los propósitos e ideales de las verdaderas universidades la que mantenía atrasada a San Marcos. Pero hoy, ante los hechos que acabo de presenciar no sólo le doy la razón, sino que me siento entristecido al pensar que está todavía muy lejano el día en que este país tenga una verdadera Universidad. [...] No puede Ud. imaginarse cuánto le he extrañado durante los últimos tiempos; cuando tuve que enfrentarme casi solo contra los catedráticos de la Universidad. Creí, que había llegado la oportunidad de emprender una seria reforma de ésta; desgraciadamente, nada se ha podido hacer hasta ahora. Su colaboración habría sido de gran importancia para el éxito de dicho propósito" (documentos $\mathrm{N}^{\circ} 8$ y 14).

Problemas de tipo personal, la escasa ayuda que Tello pudo o quiso proporcionar a Zulen ante sus reiterados pedidos desde Cambridge por el abandono económico del gobierno ${ }^{20} \mathrm{y}$, al parecer, resentimiento mutuo por comentarios negativos de Zulen sobre la política del gobierno y el proyecto de ley universitaria presentado por Tello (documentos $\mathrm{N}^{\circ} 12 \mathrm{y}$ $15)^{21}$, y la visión negativa que éste expresara sobre Manuel Vicente Villarán, entonces rector de San Marcos y, desde siempre, amigo y protector de Zulen (documento $\mathrm{N}^{\circ} 14$ ), terminaron por distanciarlos. De vuelta en Lima, Zulen aprovechó la primera oportunidad que tuvo para expresar a Tello su deseo de limar asperezas y reanudar su amistad: "Las triviales cosas ocurridas entre los dos no son 
para separar a quienes si bien opinan de modo distinto en cuanto a oportunidad y medios o procedimientos, están completamente de acuerdo en ideales y propósitos" (documento $\mathrm{N}^{\circ} 16$ ).

Y es que ambos compartían el anhelo de construir un país nuevo, una nación basada en la reconstrucción de nuestro pasado indígena prehispánico y la defensa de los derechos e intereses de las grandes mayorías rurales, es decir, del campesinado ${ }^{22}$. En una de sus cartas, Tello sostenía: "Usted sabe que no puede haber patria en el aire, sin base de sustentación, que en la nuestra está constituida por la historia de la raza cuya civilización no ha sido comprendida" (documento $\left.\mathrm{N}^{\circ} 8\right)^{23}$.

La correspondencia finaliza en octubre de 1922. Desconocemos lo sucedido entre ambos hasta la muerte de Zulen, acaecida el 27 de enero de 1925 . Una corona fúnebre enviada por Tello queda como último testimonio de lo que fue una amistad ${ }^{24}$. Una investigación más exhaustiva sobre estos dos últimos años tal vez aclaren en el futuro nuestras dudas al respecto.

\section{LA CORRESPONDENCIA}

El apéndice documental que va a continuación, con 17 cartas en total, fue ubicado y trabajado en dos repositorios: en primer lugar, las ocho cartas remitidas por Tello a Zulen fueron tomadas del archivo de manuscritos que atesora la Biblioteca Nacional, en la denominada «Colección Pedro S. Zulen», que fuera conservado por Petronila Aymar, su madre, y Elvira Zulen, su hermana, durante casi sesenta años y que hoy se encuentra en proceso de organización y catalogación ${ }^{25}$.

Las nueve cartas restantes, remitidas por Zulen a Tello, se encuentran en el llamado
"Archivo Tello», perteneciente al Museo de Arqueología y Antropología de la Universidad Nacional Mayor de San Marcos ${ }^{26}$. El Museo se encuentra hoy dedicado a la publicación de los manuscritos inéditos de Tello, dando prioridad a su trabajo arqueológico, por lo que éste es el primer grupo de cartas pertenecientes a su correspondencia que se publica.

\section{APÉNDICE DOCUMENTAL}

\author{
$N^{\circ} 1$ - Julio C. Tello a Pedro S. Zulen \\ (Lima, enero 27 de 1914). ${ }^{27}$
}

Querido Zulen:

Probablemente no estaré a [conocerlo?] ante de [ilegible] 71/2. Hoy me es imposible el realizar la tan deseada visita; estoy muy ocupado y Palma tiene clase de alemán ${ }^{28}$. Dispense usted don Pedro. Respetos de su muy afectísimo amigo

[impreso] Julio C. Tello

$\mathrm{N}^{\circ} 2$ - Pedro S. Zulen a los delegados de la Asociación Pro Indígena en los departamentos del sur (Lima, abril 21 de 1915). ${ }^{29}$

El Secretario General de la Asociación ProIndígena, que suscribe, tiene el agrado de recomendar eficazmente al socio activo portador, doctor Julio C. Tello, a los delegados y miembros de la Asociación en los departamentos de Arequipa, Puno y Cuzco, para que se sirvan suministrarle los datos que faciliten sus investigaciones de carácter científico relacionadas con la civilización y la cultura de la raza indígena.

Delegados:

Acomayo, José Ángel Escalante, Juan Crisóstomo Flores.

Anta, José Félix del Castillo. 
Aplao, Felipe Santiago Rosas, Manuel Zúñiga y Zúñiga.

Arequipa, Jorge Polar, Francisco Mostajo.

Ayaviri, Feliciano R. Sánchez.

Calca, Jesús M. Covarrubias.

Cuzco, Luis Felipe Aguilar, José Coello y Mesa.

Chuquibamba, J. Fernández Hernani, J. Sebastián Becerra.

Lampa, Francisco Chuquihuanca Ayulo.

Mollendo, Manuel T. Escalona.

Ollantaytambo, Camilo Astete.

Puno, Manuel A. Quiroga.

Sandia, Carlos R. de la Fuente.

Santa Ana (La Convención), Celedonio Monteagudo, Enrique Rosell.

Santa Rosa de Ayaviri, E. Rivero Caballero.

Sicuani, Julio C. Acureo, Maximiliano Miranda.

Urubamba, Juan de la Cruz Flores.

Yanaoca, Daniel López.

Paruro, Isaac Caparó Fernández.

$\mathbf{N}^{\circ} 3$ - Julio C. Tello a Pedro S. Zulen

(Lima, junio 12 de 1919). ${ }^{30}$

Querido Zulen:

Sentí muchísimo cuando supe que había usted sido víctima de la infamia de sus enemigos. ¿Qué otra cosa se puede esperar en un país como este donde todavía no se ha aprendido a respetar la elevación de espíritu y el gran corazón de hombres como usted? Vale usted demasiado para librarse de la persecución y envidia. Felizmente los que lo conocen a usted saben bien cuan digno es de estimación y respeto. No se mortifique Zulen. Siga usted que no son pocos los que lo admiran y aprecian.

Todo lo referente a la excursión que practiqué últimamente se publicará a fines de este año por cuenta de la universidad.
No he tenido ocasión de ver a Uhle porque había ya partido por el norte cuando yo llegué a esta. Supongo que aun continuará resentido conmigo. Me tiene sin cuidado pues mi conciencia se halla tranquila. Muchas gracias por el delicioso Transcript. Reciba cordial abrazo de su amigo.

[firmado] Julio C. Tello

$\mathbf{N}^{\circ} 4$ - Julio C. Tello a Pedro S. Zulen, Cambridge (Lima, julio 16 de 1920). ${ }^{31}$

Querido Zulen:

Hasta ahora no recibo su dirección aunque yo esperé que me la enviaría tan pronto como llegara a los Estados Unidos. Por aquí siempre bregando por vencer las dificultades que usted sabe aparecen cuando uno desea vivir la vida civilizada. Como supongo que tendrá ocasión de ver a Means, ${ }^{32}$ mucho le agradeceré le diga que sólo espero que venga para comenzar la labor que deseamos emprender en el museo. Corbacho y Quintanilla movieron el cielo para obligar a Leguía a que le cancelara su contrato, ${ }^{33}$ felizmente nada han hecho hasta ahora y espero que no harán porque creo haber convencido al presidente sobre el beneficio que le reportará al país el que organice científicamente su museo.

Mi sobrino Godofredo lleva esta carta y él le enviara su dirección. Va en busca de trabajo y de estudio. Tiene apenas treinta dollars mensuales pero una gran voluntad por ser algo y creo que lo conseguirá en ese gran país. Ojalá le fuere a usted posible aconsejarle y si posible le fuere ayudarle a que realice sus propósitos. Ya sabe usted que soy en este país el primero en reconocer y admirar sus méritos. Todavía no se ha presentado oportunidad de ayudarle en lo mucho que usted aspira, pero querrá Dios que pronto tenga que comunicarle alguna grata noticia para usted. 
Reciba usted el fraternal abrazo de su amigo y admirador,

[firmado] Julio C. Tello

$\mathbf{N}^{\circ} 5$ - Pedro S. Zulen a Julio C. Tello, Lima (Cambridge, julio 29 de 1920). ${ }^{34}$

Mi querido amigo:

Desde el 26 me hallo aquí después de dos semanas de estadía en New York. De salud estoy perfectamente bien. Estoy usando ya la Biblioteca de Harvard como próximo alumno (pues me registraré en setiembre) de la Escuela Graduada de Artes y Ciencias, pudiendo sacar seis libros a la vez y consultando directamente en el stall. Deferencia del decano Haskins, quien me recibió lo más cariñosamente y recordó mi artículo "Harvard y San Marcos"35, que dijo le había gustado mucho.

Anoche fui a una conferencia dada por Belaunde en la Universidad (Emerson Hall) sobre poesía hispano-americana. ¡Qué vaciedad, Dios mío! Una conferencia sin plan, pero con teatro y hojarasca descomunal. Rubén Darío estaba bajo Gutiérrez Nájera y José Asunción Silva. Alberto Ureta colocado en el mismo sitio de Amado Nervo y Silva. Gálvez confundido con Eguren. Iberico equiparado con González Prada. Sobre Chocano se limitó a repetir lo escrito por Ventura García Calderón. Ni una sola referencia a Herrera Reisig, Lugones, Valencia, González Martínez, Gabriela Mistral. El público sería como de cincuenta personas, pero solo unos cuantos que se conocía que hablaban o comprendían el castellano, habrán podido apreciarlo. Es natural que haya metido la pata. ¿Cuándo ha sido Belaunde crítico literario? ¡Pobre Universidad, pobre país que así creen prestigiarse! $!^{36}$

Yo preparo ahora la edición inglesa de mi librito sobre Bergson ${ }^{37}$. Hágame el favor de saludar a las señoritas Palma, a quienes les escribiré después que vea a [al margen] Goldberg para preguntarle sobre la traducción inglesa de Vencida ${ }^{38}$. Goldberg publicó ayer un artículo en el Transcript, analizando el libro de Juan Ignacio Gálvez sobre el Perú y su política internacional. Le he enviado una carta de rectificación.

[Al margen] Salude a la señora y usted reciba un fuerte abrazo de su amigo

\section{[rubricado] Pedro S. Zulen}

$\mathbf{N}^{\circ} 6$ - Julio C. Tello a Pedro S. Zulen (Lima, octubre 15 de 1920). ${ }^{39}$

Mi muy querido Zulen:

Anteayer le dije al nuevo ministro señor Barros que tuviere la bondad de atender a su apoderado en el asunto que me recomien$\mathrm{da}^{40}$. Creo que en estos días recibirá lo que se le adeuda.

No puede usted imaginarse cuanto lo envidio. Aquí me tiene usted, como siempre, lleno de mortificaciones, lejos de todos y de todo en este ambiente de indiferencia y de inercia.

Sé que Corbacho me hizo labor allá y con éxito; pues según me informan el embajador Pezet se opuso a que se realizara la invitación del Instituto Arqueológico de América para que fuere yo su huésped el próximo mes de diciembre. No me preocupa. $\mathrm{Al}$ fin voy a realizar mis aspiraciones de años atrás. Va a publicarse una revista de arqueología y yo seré el editor. El señor Larco proporcionará los medios y la revista saldrá con regularidad. Aun en el caso no probable que también el propio señor Larco se volviera contra mí, estoy resuelto a sostener la revista hasta que sea conocida y apreciada ${ }^{41}$. Dispense la inmodestia; pero así lo creo querido Zulen, porque lo que en ella voy a publi- 
car representa la labor de algunos años ya y más que todo representa muchas amarguras $\mathrm{y}$ aunque se trate de trabajos mediocres o inútiles tienen para mí la explicación de mi silencio y hasta de mis fracasos en los asuntos públicos en los que me he visto obligado a actuar.

Mi familia pretende establecerse definitivamente en los Estados Unidos tan pronto como quede yo aquí sin recursos, o mejor tan pronto como dejare el gobierno el señor Leguía. Considero que debo vivir siquiera en los últimos años de mi vida en aquel gran país que tuve la suerte de apreciar en el cortísimo tiempo que residí en Cambridge.

Escríbame con frecuencia y cuente usted como siempre con la sincera amistad de su admirador,

[firmado] J.C. Tello

\section{$\mathbf{N}^{\circ} 7$ - Pedro S. Zulen a Julio C. Tello, Lima (Cambridge, marzo 29 de 1921). ${ }^{42}$}

Querido amigo:

Escrita mi anterior, he sabido después que el gobierno había acordado suspender las pensiones desde julio próximo. De modo que lo que le pedí gestionara a mi favor queda ya sin lugar. ¿Cree usted que se podría conseguir un consulado, por ejemplo el de Boston, pero rentado? Si eso fuera posible, quedaría muy bien por pequeña que fuera la renta; sería para mí un [sic] gran ayuda y así podría continuar mis estudios.

No deja de ser una buena cosa el suspender los pensionados; lo malo es que por los que no lo merecían pagan también los que eran más acreedores a ellos. Unos volverán al no tener quien los sostenga aquí. Otros se quedan por su cuenta o a trabajar para sostenerse por sí mismos. Esto último creo es lo que me tocará a mí, pues veo difícil conseguir algo. Si lo intento, molestándolo es porque creo que no hay peor gestión que la que no se hace.

Me han escrito de esa diciéndome que en la calle se dice que yo me he casado con Dora Mayer ¿Ha visto usted cosa igual? Supongo que usted no habrá dado crédito a semejante locura. Me dicen que ella se firma como si se hubiera realizado tal cosa, y que ha publicado un folleto con tal nombre ${ }^{43}$. Usted comprenderá que esa no es sino una forma, para mí inesperada, de su antigua persecución. Lo autorizo para desmentir esto si se ofrece la oportunidad.

Llegan hasta aquí los rumores de que la situación por allá está muy mala y que se espera un movimiento. ¡Qué país tan desgraciado el nuestro!.

Salude a la señora y usted reciba un fuerte abrazo de su amigo muy suyo,

[rubricado] Pedro S. Zulen

P. D. - No sé si le comuniqué en mi anterior que había dado una conferencia con éxito en el Club Español, en Boston, y que se publicó en The Irish Republic, mi oración a Irlanda, en inglés ${ }^{44}$. Creo habérsela mandado esta última en uno de los paquetes de periódicos que regularmente le mando.

$\mathbf{N}^{\circ} 8$ - Julio C. Tello a Pedro S. Zulen, Cambridge (Lima, mayo 31 de 1921). ${ }^{45}$

Estimado amigo:

Aun no me ha sido posible conseguir del gobierno lo que usted solicita; hace pocos días hablando con el presidente le manifesté algo sobre la importancia y seriedad de los estudios que usted lleva a cabo y sobre la necesidad de prestarle decidido apoyo; puedo asegurarle que le ayudará tan pronto como mejore algo la situación económica. 
Supongo que ya se habrá enterado sobre los desgraciados sucesos acontecidos aquí y que han traído consigo la casi anarquía en la Universidad. Nuestro amigo Belaunde, a quien usted como nadie conoce a fondo, ha sido el iniciador de lo sucedido. Pretendiendo echar abajo al gobierno envolvió a la Universidad en la política que ha traído como consecuencia el retiro de ella de los más prestigiosos profesores.

Una vez, yo mismo censuré la forma acalorada de algunos de sus artículos referentes a la mala organización de la universidad; creí que no era tanto ignorancia de los propósitos e ideales de las verdaderas universidades la que mantenía atrasada a San Marcos. Pero hoy, ante los hechos que acabo de presenciar no sólo le doy la razón, sino que me siento entristecido al pensar que está todavía muy lejano el día en que este país tenga una verdadera Universidad. Los profesores que sólo tienen el nombre de tales, pues en cualquier otra parte del mundo serían simples repetidores fonográficos no se han tomado el trabajo de estudiar la historia de la institución universidad, ni mucho menos conocer los fines que ella persigue. ¿Cuántos años transcurrirán para que se establezca aquí el curso de investigación científica o seminario alemán que es lo único que nos servirá para progresar? Imagínese usted lo que serían Harvard, Columbia o Berlín sin los seminarios o cursos de research?

Desde hace quince días me tiene usted fuera del Museo Larco Herrera. Fui el iniciador, el peón, el colector y el investigador durante año y medio; creí llegada la oportunidad para formar el gran instituto que desde hace ya más de 10 años llevo en la mente y en el corazón. Usted sabe que no puede haber patria en el aire, sin base de sustentación, que en la nuestra está constituida por la historia de la raza cuya civilización no ha sido comprendida.
Le desea todo género de felicidades su afectísimo amigo y seguro servidor

[firmado] Julio C. Tello

No 9 - Pedro S. Zulen a Julio C. Tello, Lima (Cambridge, junio 29 de 1921). ${ }^{46}$

Querido amigo:

Mucho le agradezco sus gestiones a favor de mí. Me hallo hace veinte días en vacaciones después de haber rendido examen en inglés. Estoy muy bien de salud y en busca de trabajo, pues mi situación es difícil por no contar ya con recursos. En el correo pasado escribí al doctor Villarán para que influyera cerca del doctor Bard a fin de que se me abonen aquí, por el consulado en New York, las tres pensiones atrasadas que se me adeudan ${ }^{47}$. Si esto se logra podré sostenerme al menos estas vacaciones, pues para el año entrante tengo ofrecida una posición para enseñar. Le ruego que haga usted por su parte algo respecto a esas pensiones, ayudando así la gestión del doctor Villarán.

La situación en que estoy es debida en parte a mi modo de ser, pues he podido dedicarme a cosas ajenas a los estudios para los cuales se me mandó, y prepararme a fijar mi residencia y porvenir por estas tierras. No lo hice así, pensando siempre en nuestro país. He aquí que ahora me veo en apuros.

Hoy estuve con el professor [sic] Tozer a ofrecer por su conducto la venta de mis libros a la Universidad. Hablamos de usted, de Means, que dice va a verlo pasado mañana y de otras cosas. Si usted le escribe, hágame el favor de recomendarme a él.

El asunto de la Universidad de San Marcos es lamentable y daña no solo a sus causantes sino al país. Antier ha salido en el Christian Science Monitor, en la primera 
columna de la primera página, un artículo de cerca de dos columnas donde se pinta de la manera más desprestigiosa para el Perú los sucesos recientes. Pasará mucho tiempo para que nosotros podamos tener una universidad digna de ese nombre. $\mathrm{Y}$ ninguna institución como San Marcos tiene el principal elemento que es su antigüedad y su influencia durante el coloniaje, para llegar a ser una gran institución. Y es que en vez de estimular y acrecentar nuestros propios elementos, los anulamos o les hacemos la vida imposible y los obligamos a salir del país y preferimos pagar grandes sueldos a extranjeros que no pueden querer a nuestro país como nosotros los peruanos. Así la Universidad se convierte en el último baluarte de la ignorancia y la política.

Lamento muy de veras la clausura del Museo Larco Herrera. He allí una desilusión más para usted y para los que como usted pensamos. Pero ¡qué se ha de hacer! Ah! si todo lo que está pasando fuera el preludio de un cambio trascendente en todas nuestras cosas! Le aseguro que nunca me he sentido más peruano que ahora.

Reciba un fuerte abrazo de su amigo muy suyo, y salude a la señora.

[rubricado] Pedro S. Zulen

$\mathbf{N}^{\circ} 10$ - Pedro S. Zulen a Julio C. Tello, Lima (Cambridge, octubre 4 de 1921). ${ }^{48}$

Querido amigo:

Sin ninguna suya a que referirme, le escribo ésta confiado en que hará algo de su parte para salvar la difícil situación económica por la que paso.

Esperaba ir a Wisconsin a trabajar, pero a pesar de las gestiones de Ross, no ha sido posible ir allá; el chairman del departamento donde iba a ingresar alega que la vacante esperada no se ha producido. He buscado trabajo en otra parte, pero éste no ha sido posible lograrlo. Trabajo físico y de otro género no es posible no tanto porque tendría que descender, cuanto porque mis antecedentes de salud no lo permiten, como usted sabe.

La única cosa con que cuento es mi salud, la cual no ha sufrido quebranto alguno hasta ahora, a pesar de los rigores del clima y del bastante trabajo intelectual que he tenido y tengo, pues si bien no he podido ganar un solo centavo, he empleado los últimos tres meses en preparar los materiales para un trabajo de aliento sobre la filosofía en este país ${ }^{49}$. He revisado todo lo que hay, echado a un lado la basura, tomado las notas respectivas y logrado el miraje de conjunto, de modo que solo me resta el escribir. Si mi situación económica mejora, me iré a Washington a usar la Biblioteca del Congreso, pues ahora que Harvard está funcionando los periódicos y libros del caso, están en mucho uso y no se les puede retener con liberalidad. En Washington hay, además, varias bibliotecas, así es que estaría en ambiente para concluir mi obra.

La mala situación me obligó a escribir al cónsul y al señor F. C. Fuchs, pidiéndole un auxilio para poder movilizarme, habiéndome decidido volver al Perú, pero estas gestiones no tuvieron éxito. El cónsul dijo que no podía dar más que pasaje y el señor Fuchs ni siquiera me contestó. Sé que hay varios a quienes se les ha prorrogado sus pensiones, no obstante ser notorio que todo su tiempo no lo han empleado más que en divertirse; y son pensiones de 300 y 220 dólares mensuales, y a mí que trabajo de verdad, por convicción y por hábito, no ha sido posible concederme nada...

Si hubiera logrado vender mis libros, ya que no tengo otra cosa a que acudir, no le molestaría, pero ante una situación que cada 
día se hace más difícil, me veo obligado a escribirle, pidiéndole gestione cualquiera cosa, aunque fuese un subsidio por una sola vez. Si yo me quedara un tiempo más, acá, podría tener hasta la posibilidad de irme a Alemania, con el fin de posesionarme de la lengua que he olvidado mucho por haber dejado un tiempo de leerla. Pero toda esperanza se quiebra cuando medito sobre $\mathrm{mi}$ presente situación.

[Al margen] De mis trabajos emprendidos en la última vacación, le contaré que merced a ellos completé la reciente bibliografía anotada de William James, publicada por uno de mis maestros en Harvard, el profesor Perry. El tiempo que tengo ahora es corto para contarle otras cosas, pero confío en que salvará a este pobre amigo que usted conoce bastante para poder confiar en su palabra.

[Al margen] Un fuerte abrazo para usted y saludos a la señora,

[rubricado] Pedro S. Zulen

$\mathbf{N}^{\circ} 11$ - Pedro S. Zulen a Julio C. Tello, Lima (Cambridge, enero 17 de 1922). ${ }^{50}$

Recordado amigo:

Ignoro hasta ahora si las varias cartas que le he escrito anteriormente hayan llegado a su poder. Le escribo hoy por si acaso ésta lo encuentra en buena disposición para el amigo.

Aquí estoy en una situación de no sé que hacer. Hace tres mes [sic] escribí al doctor Bard, pidiéndole el pago de aquel adelanto que se me acordó al venir, en junio de 1920 , para con ese dinero volverme inmediatamente al país, pero ese caballero ni se ha dignado contestarme. Si yo no tuviera a mi padre enfermo y a mi familia en necesidad, no es- taría rogando y a personas que parece nunca hubieran estado en necesidades.

Felizmente estoy muy bien de salud, y mal que bien he tenido con que comer, pero debo varios meses de casa y éstos tengo que pagarlos por más buenos que hayan sido conmigo los dueños. Lo único que deseo es que se me envíe ese dinero cuanto antes, aunque sería de desear se me aumentase la suma, pues si ahora tres meses eran suficientes para pagar lo que debo, hoy ya no lo son, y quedaría en las mismas, sin poder marcharme, que es hoy mi ansia. Me convendría quedarme un poco tiempo más, pero ante la dificultad de hallar trabajo y sin auxilio ninguno de nuestro gobierno - pues ni para barredor de un consulado puedo servir- sólo deseo volverme a mi casa.

Si usted hace algo esta vez por este pobre amigo, ello vendrá como una cosa providencial, tal es la triste situación en que me hallo.

Mis expresiones a la señora, con mis mejores deseos por su bienestar y el de usted

[rubricado] Pedro S. Zulen

No 12 - Pedro S. Zulen a Julio C. Tello, Lima (Cambridge, febrero 3 de 1922). ${ }^{51}$

Querido amigo:

$\mathrm{Al}$ fin se acordó usted de que existía! En el correo pasado ${ }^{52}$ recibí su Introducción a la historia antigua del Perú, trabajo que me ha agradado mucho y que honra a la ciencia y al país ${ }^{53}$. No es para mí, en este momento, propicio hacer algunas observaciones que su lectura me ha sugerido, por eso sólo me limito a preguntarle qué fonética usa usted para decir Wanka, Tiawanaco, Tawuantinsuyo, Kontisuyo, Pre-Inkana, etc. ${ }^{54} \mathrm{Sin}$ embargo, veo Tiahuanaco en la página 7, en la 21 , acaso por error de imprenta. 
Así pequeño y condensado, su trabajo es rico en observaciones y puntos de vista, y acaso puede constituir el principio de una nueva manera de investigar y concebir la arqueología peruana. Hay el derecho de esperar la obra definitiva.

¿Cómo anda lo de la Universidad? ¿Todavía los mismos egoísmos? Y todos esos americanos, ¿qué han hecho o están haciendo? Lo que es, si todos son por el estilo de Bard, creo que lo único que se ha hecho es botar la plata, aparte de que es camino muy errado aquel de llevar profesores extranjeros y dejar perecer al elemento nacional. Del famoso Bard, le diré que sólo lo que hizo cuando fue consultor de la comisión presidida por Villarán, bastaría para evidenciar que ese individuo no sabe nada de instrucción. La instrucción, en todas partes se reforma estudiando por sí mismos sus defectos y corrigiéndolos, pero en ninguna parte se busca profesionales del extranjero para que vayan a arrasar con la realidad viva nacional. Quizá el hecho de estar allá y dentro del régimen actual, no le haga ver las cosas con claridad, pero en esta carta hablo de hombre a hombre, $\mathrm{y}$ a un hombre que sabe de honradez y de verdad. Nosotros en materia de instrucción tenemos que volver a esa época en que ese afán de desnacionalizar no había aparecido todavía, el cual principia con la primera administración Pardo. Los hombres que en el Perú han dado con la realidad no son más que Labarthe, por un lado, y Capelo, por otro. Todos los demás adolecen de falta de sentido de la realidad, y me parecen como otros de por aquí, que creen que estas universidades por tener grandes edificios y medios son realmente universidades.

He querido escribir sobre esto, pero desalentado y moralmente errante, como estoy aquí, pasando trabajos, no hay ganas para nada.
Espero que me escribirá pronto. Salude a la señora y reciba usted un fuerte abrazo de su amigo,

[rubricado] Pedro S. Zulen

$\mathrm{N}^{\circ} 13$ - Pedro S. Zulen a Julio C. Tello (Cambridge, abril 11 de 1922). ${ }^{55}$

Recordado amigo:

Después de su atenta de enero 25 no he tenido ninguna grata suya. Le escribí al recibir su Introducción a la historia antigua del Perú, carta que supongo ya llegada a sus manos.

Como el dueño de casa tenía que cansarse de esperar el pago de la habitación que ocupaba en 20 de Trowbridge St., me he mudado, dejando en depósito todos mis libros (3 baúles), hasta que pueda cancelar la deuda. Naturalmente he tenido que señalar un plazo, que es de dos meses, en la esperanza de que ya para entonces haya alguna respuesta favorable de usted acerca de sus gestiones ante el gobierno. Muy fácil me sería cambiar mi nacionalidad y desligarme completamente de mi patria, pues la necesidad es muy mala consejera; pero si actualmente hay pensionados, y que, al menos hasta diciembre último, como me consta, algunos antiguos recibían pensión, ¿por qué causa no podría yo recibir un pequeño auxilio por una sola vez? Usted que conoce mi pasado y me conoce individualmente ¿permitirá que tenga que desvincularme completamente del país?

Salude a la señora y crea en su amigo, [rubricado] Pedro S. Zulen

$\mathrm{N}^{\circ} 14$ - Julio C. Tello a Pedro S. Zulen, Cambridge (Lima, junio 3 de 1922). ${ }^{56}$

Querido Zulem [sic]:

No por negligencia, porque aquello sería imperdonable dada la sincera amistad que 
nos une y sobre todo la admiración y respeto que me inspira su vida y su labor, sino por las dificultades que aquí, como usted bien sabe, se presentan cuando se trata de ayudar a todo aquello que se juzga digno, no se le ha enviado a usted lo que tan insistentemente ha solicitado. Visité al ministro en varias oportunidades; le hablé al propio presidente de la República, obtuve de ellos, como se obtiene siempre que se solicita aquí algo, el más decidido ofrecimiento. Al fin se envió la orden con fecha 5 de abril al cónsul de New York para que se le abonara una pensión y los gastos de viaje. Solicité nuevamente, al recibir su carta del 11 de abril, que se le concediera un nuevo auxilio y su pasaje de regreso al Perú; también me han ofrecido, y abrigaba la esperanza de tener el placer de cablegrafiarle de un momento a otro. Ha habido una confusión en el ministerio sobre mi gestión última con la primera; de esto me ocupo y haré todo lo posible por conseguir lo que usted desea, a pesar de que la situación económica del Estado, es como usted no lo ignorará, sumamente grave. Me han ofrecido que se le atenderá, y espero que pronto será real dicho ofrecimiento.

No puede Ud. imaginarse cuanto le he extrañado durante los últimos tiempos; cuando tuve que enfrentarme casi solo contra los catedráticos de la Universidad. Creí, que había llegado la oportunidad de emprender una seria reforma de ésta; desgraciadamente, nada se ha podido hacer hasta ahora. Su colaboración habría sido de gran importancia para el éxito de dicho propósito. Nuestro admirado Villarán va resultando en mi concepto más conservador que Prado. En el discurso que pronunciara al reabrir la Universidad, sostiene principios totalmente opuestos a los que él sostuviera, primero en 1904 y después en 1912. Se ha identificado con los deseos de los que creen que la Universidad no debe ser sino una institución burocrática, y ha sostenido, aun- que parezca increíble, que la actual Universidad, tiene una magnífica organización y que lo único que necesita, es dinero para pagar grandes sueldos a los actuales catedráticos; sueldos señalados por la ley de 1920 , que fija libras peruanas 80 para los catedráticos principales, libras peruanas 62.5.00, para los auxiliares, mensualmente.

Sería muy largo reseñarle todo lo acontecido últimamente con este problema universitario, que a usted en otras oportunidades le preocupó mucho.

No me parece propio que piense usted en la tontería de cambiar de nacionalidad. Venga al Perú que aquí somos ya no pocos los que pensamos como usted, los que amamos sinceramente el estudio y trabajamos por la realización de ideales superiores a los que mueven aquí a los hombres que atienden solo a sus intereses egoístas.

Consérvese bien, y reciba como siempre el cariñoso saludo de su amigo y seguro servidor.

[firmado] Julio C. Tello

[Tarjeta adjunta: ${ }^{57}$ El ministro de Justicia. O. C. Barrós saluda atentamente a su distinguido amigo señor Dr. Julio C. Tello, y cumple con manifestarle que, conforme le había ya anticipado el cónsul del Perú en New York, sólo paga a los pensionados con orden del Ministerio de Hacienda.

Habiéndose dirigido la respectiva comunicación a dicho ministerio para el pago de una pensión y gastos de viaje de su recomendado don Pedro Zulen, le insinúa la conveniencia de gestionar ante ese despacho, el pronto envío de la mencionada orden.

Lima, 8 de mayo de 1922. 
$\mathbf{N}^{\circ} 15$ - Pedro S. Zulen a Julio C. Tello, Lima (Cambridge, julio 2 de 1922)..$^{58}$

Querido amigo:

Al fin vino carta de usted, pero todavía nada positivo para salir de la difícil situación que atravieso. Ojalá logre la orden del Ministerio de Hacienda, y yo le pediría que dicha orden la hicieran por cable a fin de poder irme cuanto antes. Hace cuatro días recibí carta de mi familia, de Lima, donde me anuncian que mi madre está tan mal que es posible no la encuentre ya el día que vuelva. He querido hacerle un cablegrama pidiéndole que gestionase se hiciera la orden de pago referida por cable, para poder llegar a tiempo y encontrar a mi madre viva, pero si no tengo para comer, menos tendré para hacer un cablegrama.

Comprendo que la situación del fisco es difícil y que más difícil es que nuestro pobre país camine por buena senda. Así es que acepto todo lo que me pasa por haber tenido un rato de optimismo y haber creído.

No llegó a mis manos su proyecto de ley encaminado a resolver la situación universitaria. Pero alguien me dijo que la Biblioteca Nacional iba a estar incluida dentro de la Universidad. Si las demás disposiciones eran así o, mejor, por este estilo, usted me perdonará, mi querido amigo, que diga era disparatado ese proyecto. Lo que nuestras instituciones necesitan es moralizarse y la moralidad no se hace con la dación de leyes escritas de lectura más o menos grata. Esto es lo que nadie en el Perú quiere comprender. Por eso es que estamos así.

El discurso de Villarán me ha parecido un discurso de política universitaria. Es decir, él ha querido hacer un block fuerte como base de sustentación y por eso aparece transando con viejos elementos y viejos moldes.
En mi opinión, la universidad no necesita por ahora reorganización sino moralización. La reorganización es un proceso y no una mera adopción de cosas nuevas en un momento determinado. Si usted implanta, por ejemplo, los seminarios, usted no puede creer nunca que por el hecho de figurar tales cosas en los programas universitarios, tiene usted realmente seminarios. Y esto lo digo no porque me parece ${ }^{59}$ tal cosa así, sino porque he sido miembro de un seminario en Harvard y he tenido la experiencia inmediata de la cosa.

Cuando yo fui auxiliar de la Biblioteca de la Universidad, e iba a emprender la obra del catálogo, el bibliotecario se opuso. Yo le dije a Villarán, entonces inspector de la Biblioteca, que con sólo fusionar la oficina de la Revista Universitaria a la Biblioteca, pasando la administración a esta última, teníanse los fondos suficientes para tener el número de empleados requerido para la catalogación, número que sería mayor llevando mujeres en vez de hombres que no hacían nada, como sucede en la oficina de la Revista y en la de la Biblioteca. ¿Qué sucedió? Yo tuve que renunciar el puesto y desde entonces se descuido la limpieza de los libros y comenzaron a picarse. Cuando yo dejé la Biblioteca no había un solo libro picado, allí no se conocía la polilla. Pero como lo que debían hacer bibliotecario y auxiliar, lo hacían los dos hombres destinados a la limpieza de los libros, estos comenzaron a picarse. Hoy ya esa estantería no sirve, y la Universidad exhibe una biblioteca sin catálogo, con libros picados y con una estantería que lleva el peligro de picar todos los libros de la biblioteca. Yo se lo dije esto a Villarán antes de marcharme del Perú, hace dos años. ¿Cuándo tendrá la Universidad Biblioteca? ¿Cuando sea más rica o cuando se moralice?

Hace un mes escribí a Villarán que estaba dispuesto a irme inmediatamente y a consa- 
grarme a la Universidad si me daban la $\mathrm{Bi}$ blioteca, puesto para el que he hecho estudios y he observado e investigado todo en este país. Sin biblioteca nunca tendremos universidad, si por universidad se entiende institución sabia y no último reducto de desocupados e ignorantes. La biblioteca es la piedra angular de la universidad.

Vamos a ver lo que me contesta Villarán. Pero si no se logra aquello, hay que abandonar toda esperanza del nuevo orden de cosas.

Mis recuerdos a la señora. Yo quedó aquí bien de salud y con la esperanza de verle pronto por allá. Su amigo,

[rubricado] Pedro S. Zulen

P. D. Me olvidaba decirle que ha terminado la conferencia de Washington, con triunfo diplomático barato para los chilenos. El Perú se ha echado encima a Bolivia, no ha sacado nada de Chile, y ha gastado la fuerza intervencionista de los Estados Unidos, fuerza que debió reservar para ocasión más seria que puede presentarse en el provenir. Desde el reconocimiento de Panamá, en 1904, el Perú sigue una errada doctrina diplomática: [al margen] El Perú en materia política internacional debe ser anti-yanqui, así como en cuestiones de reforma nacional no debe buscar inspiraciones yanquis ni extranjeras, sino purificar y consolidar su propia personalidad.

La conferencia de Washington es una lección para los que creen que el problema peruano-chileno no es problema de moraliza- ción interior peruana; y es una dura lección para el pueblo peruano explotado por el chauvinismo pícaro de los políticos peruanos. Vale.

No 16 - Pedro S. Zulen a Julio C. Tello (Lima, octubre 10 de 1922). ${ }^{60}$

Recordado amigo:

Aunque una incomprensión de ambos nos mantiene alejados, un folleto infame y canallesco que ha llegado a mis $\operatorname{manos}^{61} \mathrm{me}$ ha decidido ha escribirle ésta.

Las triviales cosas ocurridas entre los dos no son para separar a quienes si bien opinan de modo distinto en cuanto a oportunidad y medios o procedimientos, están completamente de acuerdo en ideales y propósitos.

Su amigo de ayer y de siempre,

[rubricado] Pedro S. Zulen

$\mathbf{N}^{\circ} 17$ - Julio C. Tello a Pedro S. Zulen (Lima, octubre 14 de 1922). ${ }^{62}$

Estimado Zulen:

Por su carta de anteayer que acaba de llegar a mis manos, he sabido que se halla usted ya en ésta. Me es muy grato saludarle y desearle felicidades en su futura actuación en el país.

De usted como siempre afectísimo amigo y seguro servidor.

[firmado] Julio C. Tello 


\section{NOTAS}

' César PACHECO VÉLEZ, "El método histórico de las generaciones y la generación peruana del Novecientos" (Pacheco 1993: 11-39).

${ }^{2}$ Importantes excepciones son los estudios sobre las jornadas de lucha estudiantil sanmarquina contra el primer gobierno leguiista (1908-12), en setiembre de 1911, y sobre el llamado Partido Nacional Democrático o «Futurista», publicados por Pedro Planas. En ambos casos, sin embargo, el gran protagonista es nuevamente uno de los «líderes» del 900: José de la Riva-Agüero y Osma. Véase: Pedro PLANAS, "El bautizo político: la manifestación estudiantil de 1911" (Planas 1994: 97-134); "El Partido Nacional Democrático (1915-1921)" (Planas 1994: 135-301).

${ }^{3}$ Planas (1994: 51) reconoce, acertadamente, el olvido de Tello "cuando se reconstruye a la generación novecentista". Razón no le falta, pues Tello es casi siempre aislado o puesto al margen de su entorno generacional por sus biógrafos, como protegiéndolo de una compañía no deseada. El caso de Valcárcel es aun más grave, ya que suele identificársele mayoritariamente con la generación del Centenario, el indigenismo radical cuzqueño de los años 20 y el prólogo que Mariátegui dedicara a su clásica obra Tempestad en los Andes, olvidando su ingreso a la Universidad San Antonio Abad en 1908, su importante papel como dirigente de la Asociación Universitaria del Cuzco, fundada en 1909, y su participación en la legendaria rebelión estudiantil de ese mismo año.

${ }^{4}$ Mejía Xesspe se refiere a Tello en términos de "ciudadano representativo de la raza aborigen [...]. Aunque su apellido es de origen español, su sangre y su espíritu son genuinamente indígenas. [...] No hay duda acerca de su origen peruano o indio por- que sus antecesores pertenecieron al tronco social de los curacas de Anan Yauyos. [...] Pero la mayor cantidad de sangre india corresponde a su ascendencia materna" (Mejía Xesspe 1967: V; 1964: 55, 57). Otro de sus biógrafos dirá: "El doctor Julio C. Tello, hombre modesto y franco, como buen científico, en sus amenas clases de San Marcos, decía constantemente a sus alumnos: «Soy indio»" (Jaguande 2001: 24).

${ }^{5} \mathrm{Al}$ igual que Pedro Zulen, Tello cursó sus estudios secundarios en el colegio particular que regentaba Pedro A. Labarthe, conocido luego como «Colegio de Lima» (Mejía Xesspe 1948: 5-8).

${ }^{6}$ Pedro PLANAS, "La formación intelectual de Julio C. Tello” (Planas 1994: 45-56).

${ }^{7}$ Sobre el inmigrante chino en el Perú, «despreciado y agredido», véase Rodríguez Pastor 2001: 223-228.

${ }^{8}$ Sobre la historia de la Asociación Pro Indígena véase el estudio pionero de Kapsoli y Reátegui (1987: 136-140), incluido originalmente en una tesis de Bachiller en Historia, sustentada en 1968; y Kapsoli 1980.

${ }^{9}$ Entre éstos encontramos figuras de la talla de Jorge Polar, Francisco Mostajo, Chukiwanka Ayulo, Luis Felipe Aguilar, José Ángel Escalante y Manuel A. Quiroga.

${ }^{10}$ Sobre este punto he tratado en "Pedro S. Zulen y la Universidad de San Marcos, 1906-1925", texto leído el 9 de mayo de 2002 en el auditorio de la Biblioteca Central durante la inauguración de la Exposición Bibliográfica, Fotográfica y Documental «Pedro Zulen, San Marcos y su Tiempo, 1889-1925», de próxima publicación. Por resolución rectoral del 16 de mayo de este año, la Biblioteca Central lleva el nombre de «Pedro S. Zulen». 
"Angélica Palma a Julio C. Tello (Barcelona, julio 23 de 1921). MAA, Archivo Tello, Correspondencia, paquete $\mathrm{N}^{\circ} 1, \mathrm{t}$. IV, f. 711 .

${ }^{12}$ Una tarjeta personal de quien fuera director del antiguo Museo de Historia Nacional entre enero de 1906 y diciembre de 1911, comunica lo siguiente: "14.I / esperará al señor P. S. Zulen en el Museo hoy a las 4 p.m.".Tarjeta de Max Uhle (enero 14?) [XZu / T35.2]; no se indica el nombre del destinatario. Uhle partió del Perú, con rumbo a Chile, a principios de 1912 (Hampe 1998: 177).

${ }^{13}$ Emilio Gutiérrez de Quintanilla (18581935) fue miembro eminente de la generación que precedió a la llamada generación «positivista» o «de la posguerra» de 1879. Miembro de la Real Academia Española de la Lengua (1886) y miembro fundador de la Sociedad Geográfica de Lima (1888) y del Instituto Histórico del Perú (1905), fue nombrado director del Museo en marzo de 1912, cargo que ocupó hasta su muerte. Tello fue nombrado jefe de la sección arqueológica del Museo en junio de 1913; sobre la base de ella creó el Museo de Arqueología y Antropología en diciembre de 1913, y se vio obligado a renunciar en marzo de 1915 (Tello y Mejía 1967: 80-81, 82-83, 98-100).

${ }^{14} \mathrm{El}$ presidente Billinghurst gobernó constitucionalmente entre el 24 de setiembre de 1912 y el 4 de febrero de 1914. La junta de gobierno que lo sucedió se mantuvo hasta el 15 de mayo, día en que juramentó como presidente provisorio el coronel Oscar $\mathbf{R}$. Benavides. Capelo asumiría esa misma noche como ministro de Fomento (Basadre 2000, XI: 2731, 2739). En sus comunicaciones, diría a Zulen: "Por fin salimos de la tiranía y su amigo Osores es el ministro de Gobierno. Podremos pues lograr mucho en bien de los indígenas y creo que su colocación en el museo de antigüedades y a no tendrá tropiezo [(feb. 5)...]. Debe ud. escribir a Tello no se descuide en el asunto museo histórico no se olvide de usted. [(feb. 9)...] Felizmente su entrevista en Huacachina con Lisson, Villarán y Eguiguren deja la esperanza que traerá algo positivo en su condición financiera, que es hoy lo esencial. El cambio político operado nos da algún campo de acción y Dios ha de querer que sea aprovechado en beneficio de ud. y quede asegurada su situación y la noble labor que ud. hace siempre [(feb. 15)]". Joaquín Capelo a Pedro S. Zulen (Lima, febrero 5, 9 y 15 de 1914). BNP, Colección Zulen, Correspondencia personal de Pedro S. Zulen [XZu / C25] [XZu / C25.1] [XZu / C25.2]. El subrayado es mío.

15 Zulen obtuvo, en cambio, su ingreso al Ministerio de Fomento en calidad de secretario, puesto en el que se desempeñó por pocos meses. Pedro S. Zulen a Arturo E. Delgado (Lima, noviembre 28 de 1914). BNP, Colección Zulen [XZu].

${ }^{16}$ Comunicación personal del Sr. Julio Tello Dueñas (Lima, enero de 2000). La trayectoria parlamentaria y política de Tello, que va de 1916 a 1930 , ha sido apenas brevemente reseñada por sus biógrafos (Mejía Xesspe 1948: 10-12; 1964: 94-96; Planas 1994: 154, 205-206, 223-224; Guzmán Palomino 1997). Algunos de los proyectos de ley que presentó estuvieron referidos al $\mathrm{Pa}$ tronato de la Raza Indígena, la conservación de monumentos históricos, la reforma del sistema universitario nacional, entre otros. Sobre este último asunto publicó una compilación de ensayos y discursos (Tello 1928; veáse también Tello 1967: 27 36).

${ }^{17}$ Joaquín Capelo a Pedro S. Zulen (Lima, junio 6 de 1919). BNP, Colección Zulen, Correspondencia personal de Pedro S. Zulen [XZu / C25.25]. Aunque el artículo mencionado por Capelo no lleva firma, es evidente que su autor conocía bien a Pedro Zulen; 
véase: "Prisión del señor Zulen" (La Cróni$c a$, Lima, junio 4 de 1919, p. 2).

${ }^{18}$ Una tarjeta impresa de la Sociedad «Ethos», fundada por Zulen y otros universitarios sanmarquinos, fue hallada junto a la correspondencia de Tello. La tarjeta lleva escrito el nombre de Zulen con fecha 27 de octubre de 1914. BNP, Colección Zulen, Correspondencia personal de Pedro S. Zulen [XZu / T35]; a la espalda van los estatutos.

${ }^{19}$ No se halló mayor información que permita comprobar la posible influencia que Tello pudo haber tenido en la elección de Harvard como destino universitario de Zulen. En uno de sus artículos éste diría: "Describir Harvard, hablar de su originalidad creadora en la enseñanza universitaria norteamericana, no es cosa fácil -Julio C. Tello, conspicuo Harvard-man, lo sabe!" (Zulen 1919-20: 9).

${ }^{20}$ En 1921, Zulen le comentaba amargamente a un amigo: "Si gozara de la pequeña pensión que tenía del gobierno, estos trabajos [sus investigaciones] podrían llevarse a efecto. Pero como carezco de padrinos, y digo de padrinos, pues los amigos de Lima ni se molestan en contestarme" (el subrayado es mío). Tello, efectivamente, le respondía con escasa regularidad (documentos $\mathrm{N}^{\circ} 10$ y 12 ).

${ }^{21}$ Como tantos otros intelectuales limeños, Angélica Palma era de la misma opinión: "Una de las manifestaciones del empeño desnacionalizador es la protección a los extranjeros con perjuicio de los peruanos. Escribiéndole yo sobre esto a mi hermano Ricardo con motivo del proyecto de caricatura de Harvard (pues no otra cosa sería en nuestro medio) que con la poco honrosa cooperación de Encinas ha presentado el amigo Tello, le decía más o menos:-dile a Tello que sólo le perdonaré los excesos a que lo llevan su yankifilia y su latinofobia, si emplea su influjo con los que mandan en que se devuelva la pensión a Zulen-Si Tello puede, no dude que lo hará [(dic. 22)...]. No se si Tello le habrá escrito a usted; a mí no me ha enviado respuesta al recado que le mandé como tampoco ha contestado a mis cartas de los primeros meses de ausencia. Ahora casi me alegro; a haber mantenido, como en otras ocasiones, correspondencia con él, no habría podido eximirme de decirle cosas desagradables acerca de su capricho por yanquizar San Marcos y destruir la obra de mi padre supeditando la Biblioteca Nacional a una universidad absurda. Y no es que yo no comprenda y admire lo mucho que de admirable hay en los Estados Unidos; pero veo lo peligroso y degradante que es calcarlos servilmente, pues, como usted acertadamente me escribe, no hay nada más triste que no tener personalidad [(may. 14)]". Angélica Palma a Pedro S. Zulen (Madrid, diciembre 22 de 1921 y mayo 14 de 1922) [XZu / P19.4] [XZu / P19.5]; el subrayado es de la propia autora. Sobre el proyecto de "Constitución Universitaria», presentado en 1921 por los diputados Encinas y Tello, véase Basadre 2000, XIV: 3433.

${ }^{22}$ Sobre el «indigenismo revolucionario» de Zulen, hacia fines de la década de 1910, y su influencia decisiva en el pensamiento de José Carlos Mariátegui, véase Leibner 1999: 58-92.

${ }^{23}$ Ese mismo año (1921), Tello publicaba lo siguiente: "Nuestra actual civilización hispano-peruana no puede levantarse sino sobre el pedestal indígena; y no puede mantenerse firme y perdurar, si no se adapta completamente al medio, si los hombres no procuran utilizar nuestros propios recursos, descubrir los secretos y maravillas de nuestra propia naturaleza, admirar la labor de nuestros antecesores, glorificar a las generaciones que vivieron en nuestro propio suelo, donde se guardan sus cenizas, y del que sacaron sus alimentos y los defendieron y utilizaron durante muchos siglos. La gene- 
ración actual está obligada a hacer revivir el pasado y recoger todo aquello que pueda glorificarlo" (Introducción a la historia antigua del Perú, en Tello 1967: 212).

24 "El sepelio del doctor Zulen" (El Comercio, Lima, enero 30 de 1925, ed. de la mañana, p. 5).

${ }^{25}$ Sobre la «Colección Zulen», en la Biblioteca Nacional, véase Paredes 1998-99.

${ }^{26} \mathrm{La}$ correspondencia del «Archivo Tello» está organizada en cuatro «paquetes»: $\mathrm{N}^{\circ} 1$ (1909-27, fs. 1-1470), $\mathrm{N}^{\circ} 2$ (1928-40, fs. 1471-3294), $\mathrm{N}^{\circ} 3$ (1941-44, fs. 3295-5367) y No 4 (1925-44, fs. 5368-6047). El primer paquete, a su vez, está dividido en cinco «cuadernillos» o tomos: I (1909-10, fs. 1145), II (1912-15, fs. 146-454), III (191620 , fs. 455-684), IV (1921-25, fs. 685-1175) y V (1926-27, fs. 1176-1470). Los paquetes y cuadernillos contienen únicamente las cartas recibidas por Tello, exceptuando el paquete $\mathrm{N}^{\circ} 4$, que incluye un grupo de copiadores de correspondencia, es decir, copias de las cartas que Tello remitía. Entre estas últimas, figuran las cartas intercambiadas con el rector de la Universidad de Panamá y con los empleados de los museos que dirigió durante su vida. En el catálogo publicado por Carlos Daniel Valcárcel, aparece la «correspondencia» conformando el grupo XXXI del archivo, sin mayores precisiones cronológicas, ni de remitentes o destinatarios, sólo la indicación del número de paquetes y su foliación, obviando completamente la división en cuadernillos (Valcárcel 1966: 72). Sobre la historia del archivo y su estado en la actualidad, véase Aponte y Novoa 1999.

${ }^{27}$ BNP, Colección Zulen, Correspondencia personal de Pedro S. Zulen [XZu / T35.1]. Manuscrito. Se trata de una tarjeta personal de Tello (lleva su nombre impreso).
${ }^{28}$ Se refiere a su gran amigo y compañero de estudios en San Fernando, Ricardo Palma Román, hijo del ilustre tradicionista (Planas 1994: 47, 55-56).

${ }^{29}$ BNP, Colección Zulen, Correspondencia de la Asociación Pro Indígena a los delegados (copiadores) [XZu]. Mecanografiado.

${ }^{30}$ BNP, Colección Zulen, Correspondencia personal de Pedro S. Zulen [XZu / T35.3]. Manuscrito. Podría leerse también como año «1915», aunque tres datos señalados en la carta parecen negarlo: Zulen fue "víctima de la infamia de sus enemigos" particularmente en junio de 1919, cuando es apresado en Jauja; Tello participó en diversas «excursiones» arqueológicas en 1913, 1915-16 y entre enero y mayo de 1919, cuando dirige la «primera expedición arqueológica» de la Universidad de San Marcos, trabajo que le permitió organizar y fundar en su claustro, el 21 de octubre de ese año, el Museo que hasta hoy subsiste; y Max Uhle, quien radicara en Chile desde 1912, partió hacia el Ecuador en 1919, año en que posiblemente estuvo de paso en Lima antes de que Tello retornara a la capital para entrevistarse con él.

${ }^{31}$ BNP, Colección Zulen, Correspondencia personal de Pedro S. Zulen [XZu / T35.4]. Mecanografiado. Sello: «Museo Arqueológico/Víctor Larco Herrera, Lima-Perú, S.A.».

${ }^{32}$ Se refiere a Philip Ainsworth Means (1892-1944), de la Universidad de Boston, nombrado director de la Sección Arqueológica del Museo de Historia Nacional, en noviembre 23 de 1920 , puesto al que se vio obligado a renunciar a los pocos meses "por la frialdad con que se le recibe, por la indiferencia de los círculos intelectuales y por la falta de una orientación gubernamental para el desarrollo de sus actividades" (Tello y Xesspe 1967: 107). 
${ }^{33}$ Tello se refiere a dos de sus grandes enemigos de juventud: Jorge Corbacho y Emilio Gutiérrez de Quintanilla, con quienes mantuvo importantes polémicas durante las décadas de 1910 y 1920 . El primero de ellos fue un importante coleccionista de objetos prehispánicos y documentos históricos, tanto coloniales como republicanos, y congresista por la provincia de La Unión. Zulen tuvo ocasión de cuestionar sus apreciaciones historiográficas y de recomendarle una lectura más atenta de los documentos de su propia colección: Pedro S. ZULEN, “Alrededor de la historia nacional. Del discurso del coronel Ballesteros, a las afirmaciones del diputado Corbacho y las campañas de El Tiempo de Lima. ¿Prado, la víctima del 79?" (El Eco de Junín, Cerro de Pasco, № 733, pp. 1-2, jul. 22 de 1918).

${ }^{34}$ MAA, Archivo Tello, Correspondencia, paquete $\mathrm{N}^{\circ} 1$, t. III, f. 664 . Manuscrito.

${ }^{35}$ Pedro S. ZULEN, "Harvard y San Marcos" (La Crónica, Lima, agosto 20 de 1919).

${ }^{36}$ Sobre su «misión universitaria» en los Estados Unidos y la mencionada conferencia en Harvard, véase: Víctor Andrés BELAUNDE, Trayectoria y destino. Memorias (Lima: Ediciones de Ediventas, 1967; vol. II, pp. 575-587).

${ }^{37}$ Pedro S. ZULEN, La filosofía de lo inexpresable: bosquejo de una interpretación y una crítica de la filosofía de Bergson (Lima: Talleres Tipográficos de Sanmartí y Cía., 1920). Dicha obra, que fuera luego corregida y aumentada para una futura segunda edición, sirvió a Zulen como tesis para graduarse de Bachiller en la Facultad de Letras de San Marcos. Un ejemplar con dedicatoria manuscrita del autor, expresa lo siguiente: "A Julio C. Tello, / afectuosamente, / [firmado] Pedro S. Zulen / Lima, junio $1^{\circ}$ de 1920". BC, Unidad de Investigaciones Bibliográficas (Fondo Reservado) [GN / 4 /
A59 / v. 174]. El ejemplar pertenece a la colección que, por disposición testamentaria del 22 de mayo de 1947, legara a la Universidad el doctor Tello.

${ }^{38}$ Angélica PALMA, Vencida. Ensayo de novela de costumbres (Barcelona: Casa Editorial P. Salvat, 1920); publicada bajo el pseudónimo de «Marianela».

${ }^{39}$ BNP, Colección Zulen, Correspondencia personal de Pedro S. Zulen [XZu/T35.5]. Mecanografiado. Sello: «Museo Arqueológico / Víctor Larco Herrera, Lima-Perú, S.A.».

${ }^{40}$ Se refiere al ministro de Estado, Oscar C. Barrós.

${ }^{41}$ Víctor Larco Herrera (1870-1934) fue tío del también coleccionista y fundador de un museo arqueológico Rafael Larco Hoyle (1901-1966). La revista, editada por Tello y publicada por el Museo de la Universidad, se hizo realidad en 1923 con el nombre de Inca. El Museo Larco Herrera inició, ese mismo año, la publicación de su propia $R e$ vista de Arqueología.

${ }^{42}$ MAA, Archivo Tello, Correspondencia, paquete $\mathrm{N}^{\circ} 1$, t. IV, f. 693. Mecanografiado.

${ }^{43}$ Dorothea Waldine Mayer, conocida como Dora Mayer (1868-1957), se autoproclamó «esposa» de Pedro S. Zulen en junio de 1920 y, desde entonces y hasta el final de sus días, agregó a su apellido el «de Zulen». Luego de la muerte de Zulen, publicó dos pequeñas obras en donde narra la historia de su «romance» y justifica su comportamiento: Zulen y yo. Testimonio de nuestro desposorio ofrecido a la humanidad (Lima: Imprenta Garcilaso, 1925) y La poesía de Zulen (Lima: Imprenta Lux de E.L. Castro, 1927).

${ }^{44}$ Pedro S. ZULEN, "To Ireland" (The Irish Republic, febrero 25 de 1921; una traduc- 
ción fue publicada por Dora Mayer, en Concordia, Lima, $\mathrm{N}^{\circ} 1: 6-7$, julio $1^{\circ}$ de 1928 ).

${ }^{45}$ BNP, Colección Zulen, Correspondencia personal de Pedro S. Zulen [XZu / T35.7]. Mecanografiado.

${ }^{46}$ MAA, Archivo Tello, Correspondencia, paquete $\mathrm{N}^{\circ} 1$, t. IV, f. 704. Mecanografiado.

${ }^{47}$ Se refiere a John L. Bard, director general de instrucción y miembro de la «misión norteamericana» contratada por el gobierno de Augusto B. Leguía.

${ }^{48}$ MAA, Archivo Tello, Correspondencia, paquete $\mathrm{N}^{\circ} 1$, t. IV, f. 717. Mecanografiado.

${ }^{49}$ Dicho estudio le sirvió para graduarse de Doctor en la Facultad de Letras de San Marcos. Pedro S. ZULEN, Del neohegelianismo al neorealismo. Estudio de las corrientes filosóficas en Inglaterra y los Estados Unidos desde la introducción de Hegel hasta la actual reacción neorealista (Lima: Imprenta Lux de E. L. Castro, 1924).

${ }^{50}$ MAA, Archivo Tello, Correspondencia, paquete $\mathrm{N}^{\circ} 1$, t. IV, f. 738. Mecanografiado.

${ }^{51}$ Ibíd., f. 738. Mecanografiado.

52 Julio C. Tello a Pedro S. Zulen (Lima, enero 25 de 1922). No se halló esta carta entre los papeles de la Colección Zulen (BNP).

${ }^{53}$ Julio C. TELLO, Introducción a la historia antigua del Perú (Lima: Sanmartí y Cía., 1921).

${ }^{54}$ Subrayado en el original.

${ }^{55}$ MAA, Archivo Tello, Correspondencia, paquete $\mathrm{N}^{\circ} 1$, t. IV, f. 777. Manuscrito.

${ }^{56}$ BNP, Colección Zulen, Correspondencia personal de Pedro S. Zulen [XZu / T35.8].
Mecanografiado. Sello: «Universidad Mayor de San Marcos / Museo de Arqueología». Adjunta a la carta iba, originalmente, una tarjeta mecanografiada dirigida a Tello.

${ }^{57}$ BNP, Colección Zulen, Correspondencia personal de Pedro S. Zulen [XZu / T35.6]. Mecanografiado, excepto el encabezado, que va impreso, y el nombre del ministro, manuscrito.

${ }^{58}$ MAA, Archivo Tello, Correspondencia, paquete $\mathrm{N}^{\circ} 1$, t. IV, fs. $810-812$. Manuscrito.

${ }^{59}$ Subrayado en el original.

${ }^{60}$ MAA, Archivo Tello, Correspondencia, paquete $\mathrm{N}^{\circ} 1$, t. IV, f. 844 . Manuscrito.

${ }^{61}$ Se refiere a la obra de Emilio GUTIÉRREZ DE QUINTANILLA, El Manco Cápac de la arqueolojía peruana Julio $C$. Tello (Señor de Huarochirí) contra Emilio Gutiérrez de Quintanilla autor de este folleto (Lima: spdi, 1922).

${ }^{62}$ BNP, Colección Zulen, Correspondencia personal de Pedro S. Zulen [XZu / T35.9]. Mecanografiado. Sello: "Universidad Mayor de San Marcos / Museo de Arqueología".

\section{AGRADECIMIENTO}

Expresamos nuestro agradecimiento a la Dra. Ruth Shady Solís, directora del Museo de Arqueología y Antropología de la Universidad Nacional Mayor de San Marcos, por permitir la consulta de los documentos del «Archivo Tello», así como a Pedro Novoa, trabajador del mencionado archivo. Igualmente, a las señoras Elisa Morales, Ana María Maldonado e Irma López, ex directoras y directora, respectivamente, del área de Investigaciones de la Biblioteca Nacional. 


\section{BIBLIOGRAFÍA}

\section{FUENTES PRIMARIAS}

\section{Archivos consultados}

BC-Unidad de Investigaciones Bibliográficas, Biblioteca Central "Pedro S. Zulen"Universidad Nacional Mayor de San Mar$\cos$ (Lima).

BNP-Colección Zulen, Biblioteca Nacional del Perú (Lima).

MAA-Archivo Tello, Museo de Arqueología y Antropología - Universidad Nacional Mayor de San Marcos (Lima).

\section{Libros, folletos y artículos citados}

TELLO, Julio C.

1913 "La Universidad Mayor de San Marcos y la Universidad de Harvard". Revista del Centro Universitario (Lima), setiembre (bibliografía de Julio Espejo Núñez, en Mejía Xesspe 1948: 34).

1928 Reforma universitaria. Ensayos y discursos. Lima: Talleres Tipográficos de Sanmartí y Cía.

1967 Páginas escogidas. Lima: Universidad Nacional Mayor de San Marcos.

TELLO, Julio C. y Toribio MEJÍA XESSPE 1967 "Historia de los museos nacionales del Perú (1822 1946)”. Lima: Museo Nacional de Antropología y Arqueología - Universidad Nacional Mayor de San Marcos. [Arqueológicas, $\left.\mathrm{N}^{\circ} 10\right]$

ZULEN, Pedro S.

1909 "El problema nacional de la educación (introducción al debate iniciado por el au- tor en el Centro Universitario)". La Prensa, Lima, mar. 26,30 y 31 , abr. $1^{\circ}$ y 3 , eds. de la mañana, p. 2, pp. 2-3, p. 2, p. 2, p. 2.

1914a "La nueva asociación «Ethos»". $L a$ Prensa (Lima), set. 26, ed. de la mañana, p. 4.

$1914 b$ "Pedantería y charlatanismo universitario”. La Crónica (Lima), oct. 16, p. 13.

1919 "Harvard y San Marcos" La Crónica (Lima), ago. 20, p. 3.

1919-20 "Harvard University". El Tiempo (Lima), dic. 21 de 1919, p. 9; ene. 4 de 1920, p. 8.

\section{FUENTES SECUNDARIAS}

APONTE MIRANDA, Delia y. Pedro NOVOA BELLOTA

1999 "El Archivo Tello y sus publicaciones". Cuadernos de Investigación del Archivo Tello. $N^{o} 1$. Arqueología del valle de Lima, pp. 13-21, Lima: Museo de Antropología y Arqueología, Universidad Nacional Mayor de San Marcos.

BASADRE, Jorge 2000? Historia de la República del Perú, 1822-1933. Lima: La República - Universidad Ricardo Palma. [8va. edición]

GONZALES, Osmar 1996 Sanchos fracasados. Los arielistas y el pensamiento político peruano. Lima: Ediciones PREAL.

GUZMÁN PALOMINO, Luis

1997 «Julio C. Tello parlamentario: en defensa de las causas justas». Hernán AMAT OLAZÁBAL (comp.), Julio C. Tello, forjador del Perú auténtico, pp. 49-60, Lima, Centro de Estudios Histórico Militares del Perú. 
HAMPE MARTÍNEZ, Teodoro

1998 "Max Uhle y los orígenes del Museo de Historia Nacional (Lima, 1906-1911)". Revista Andina (Cuzco), No 31: 161-186.

JAGUANDE D'ANJOY, Alfonso 2001 El sabio Julio C. Tello. Lima: Printing Service. [ed. original, 1985]

KAPSOLI, Wilfredo 1980 El pensamiento de la Asociación Pro Indígena. Cuzco: Centro «Bartolomé de Las Casas».

KAPSOLI, Wilfredo y Wilson REÁTEGUI 1987 El campesinado peruano. Lima: Universidad Nacional Mayor de San Marcos. [ed. original, 197?]

LEIBNER, Gerardo

1999 El mito del socialismo indígena en Mariátegui. Lima: Pontificia Universidad Católica del Perú.

MEJÍA XESSPE, Toribio

1948 "Apuntes biográficos sobre el doctor Julio C. Tello". Revista del Museo Nacional de Antropología y Arqueología (Lima), vol. II, No 1-2, sobretiro.

1964 «Julio C. Tello». Hernán ALVA ORLANDINI (ed.), Biblioteca hombres del Perú, $3^{\mathrm{a}}$ serie, vol. XXVIII: 51-111, Lima: Editorial Universitaria.
1967 “Prólogo", Tello 1967: V-XXIII.

LOAYZA, Luis

1990 Sobre el Novecientos. Lima: Hueso Húmero Ediciones.

\section{PACHECO VÉLEZ, César}

1993 Ensayos de simpatía. Sobre ideas y generaciones en el Perú del siglo XX. Lima: Universidad del Pacífico.

PAREDES LARA, Jorge

1998-99 "El novecentista Pedro S. Zulen y la Asociación Pro-Indígena a través del archivo histórico de la Biblioteca Nacional del Perú". Fénix (Lima), № 40-41: 79-100, Biblioteca Nacional del Perú.

\section{PLANAS, Pedro}

1994 El 900. Balance y recuperación. Lima: Centro de Investigación y Tecnología para el Desarrollo de las Ciencias Sociales.

RODRÍGUEZ PASTOR, Humberto 2001 Hijos del celeste imperio en el Perú (1850-1900). Migración, agricultura, mentalidad y explotación. Lima: SUR, Casa de Estudios del Socialismo. [ed. original, 1989]

\section{VALCÁRCEL, Carlos Daniel (ed.)} 1966 El Archivo Tello. Lima: Universidad Nacional Mayor de San Marcos. 